\title{
Compost effects on microbial biomass and soil $P$ pools as affected by particle size and soil properties
}

\author{
S. Lata Verma ${ }^{1}$, P. Marschner ${ }^{1 *}$

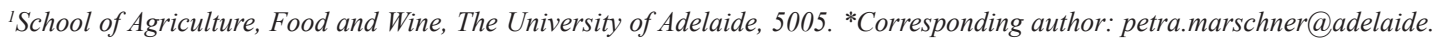 \\ edu.au
}

\begin{abstract}
Previous studies have shown that finer composts release nutrients more quickly than coarse composts, but little is known about the nutrient release from different size fractions of a compost. To assess if compost size fractions differ in their effect on microbial biomass and soil $\mathrm{P}$ pools, a compost from garden waste was separated by sieving into different particle size fractions ( $>5 \mathrm{~mm}, 3-5 \mathrm{~mm}$ and $<3 \mathrm{~mm}$ ) and then mixed into three different soils (referred as soil $\mathrm{A}, \mathrm{B}$ and C) at a rate of $50 \mathrm{mg}$ total $\mathrm{P} \mathrm{kg}^{-1}$. These soils were chosen because the size of soil $\mathrm{P}$ pools could be affected by soil properties which may also influence how the $\mathrm{P}$ pools respond to compost addition. Cumulative soil respiration, microbial biomass and soil $\mathrm{P}$ pools were determined after 25 and 50 days. Compost addition increased soil respiration and micobial biomass $\mathrm{C}$ and $\mathrm{P}$, with the greatest increase in respiration with the $>5 \mathrm{~mm}$ fraction and in microbial biomass $\mathrm{C}$ and $\mathrm{P}$ with the $<3 \mathrm{~mm}$ fraction. The size of the $\mathrm{P}$ pools was mainly affected by soil type, the compost fractions had similar effects on soil $\mathrm{P}$ pools except for a greater increase in available $\mathrm{P}$ concentration by the finest fraction compared to the coarser size fractions. Soil A with the highest organic matter content had the highest concentrations of $\mathrm{Fe} / \mathrm{Al}$ associated $\mathrm{P}(\mathrm{NaOH}-\mathrm{P})$ and organic $\mathrm{P}$ whereas $\mathrm{Ca}$-associated $\mathrm{P}(\mathrm{HCl}-\mathrm{P})$ dominated in the alkaline soil $\mathrm{C}$. The size of most $\mathrm{P}$ pools, even the so-called stable $\mathrm{P}$ pools changed over time in amended and non-amended soils. It can be concluded that the size of $\mathrm{P}$ pools is more strongly affected by soil properties such as organic matter content, texture and $\mathrm{pH}$ than by the compost fractions.
\end{abstract}

Keywords: size fractions, soil properties, temporal changes

\section{Introduction}

Phosphorus deficiency is a major constraint for crop production in many soils due to the poor solubility of $\mathrm{P}$ salts and $\mathrm{P}$ fixation which lead to low $\mathrm{P}$ availability even when total $\mathrm{P}$ concentrations in the soil are high. Fertilisers with high concentrations of soluble $\mathrm{P}$ are used to increase plant $\mathrm{P}$ availability, but $\mathrm{P}$ availability rapidly decreases as fertiliser $\mathrm{P}$ reacts with $\mathrm{Al}$ and $\mathrm{Fe}$ in low $\mathrm{pH}$ soils and with Ca in high pH soils (Bertrand et al., 2003; Khan and Joergensen, 2009). This insoluble accumulated $P$ can be released in particulate form into surface water and lead to eutrophication ( Song et al., 2007).

Application of $\mathrm{P}$ in the form of organic materials such as manures, plant residues and compost may 
provide alternative $\mathrm{P}$ sources for plants directly and indirectly. Directly by adding $\mathrm{P}$ to the soil and indirectly by release of organic acids, which block $\mathrm{P}$ adsorbing sites in the soil and by changes in soil $\mathrm{pH}$ and complexation of soluble $\mathrm{Al}$ and $\mathrm{Fe}$ (Ayaga et al., 2006; Hue, 1991). The effect of added organic material on soil $\mathrm{P}$ availability not only depends on its $\mathrm{P}$ concentration but also on soil type, solubilty and mineralisation of organic $\mathrm{P}, \mathrm{C} / \mathrm{P}$ ratio ( Peters et al., 2011) but also on particle size (GómezMuñoz et al., 2011). Large particles have a smaller surface area to volume ratio and are therefore less accessible to microbes than the finer particles. Additionally, the coarser fractions may have lower $\mathrm{N}$ and $\mathrm{P}$ concentrations than the finer fraction because of the pre-dominance of C-rich compounds (Tognetti et al., 2008) In a previous study it has been shown that finer composts released more $\mathrm{N}$ and $\mathrm{P}$ than coarse compost (Duong et al., 2012). Compost application can also indirectly increase nutrient availability by increasing microbial activity and abundance (Pascual et al., 1997; Annabi et al., 2007) and enzyme activity (Ferreras et al., 2006) which can be explained by the supply of labile organic C with compost (Annabi et al., 2007) and the increased total soil organic $\mathrm{C}$ content (Pascual et al., 1997; Ferreras et al., 2006). The relationship between particle size of composted organic material and $\mathrm{C}$ and $\mathrm{N}$ dynamics in the soil was studied by Doublet et al. (2010) and Fangueiro et al. (2008) and $\mathrm{N}$ mineralisation was greater in fine particles of manures and compost (Tester et al., 1979). However little is known about the effect of different compost fractions on $\mathrm{P}$ release and $\mathrm{P}$ pools of soils differing in properties. The comparison of different soils amended with the same compost is useful because it can show which soil properties affect compost decomposition and the size of $\mathrm{P}$ pools. The aim of the present study was to determine the effect of different size fractions derived from one compost on microbial biomass and $\mathrm{P}$ pools in soils with different texture, organic matter content and $\mathrm{pH}$.

\section{Materials and Methods}

\subsection{Experimental setup}

The three different soils used in this experiment were collected from 0-10 cm at Mount Bold, South Australia $\left(35^{\circ} 06^{\prime} 53^{\prime \prime} \mathrm{S}\right.$ and $\left.138^{\circ} 41^{\prime} 18^{\prime \prime} \mathrm{E}\right)$ and Birchip,Victoria (between latitudes $35^{\circ} 10^{\prime}$ and $39^{\circ} 54^{\prime} \mathrm{S}$ and longitudes $143^{\circ} 04^{\prime}$ and $02^{\circ} 78^{\prime}$ E) (Table 1). The soils were air dried and sieved to $<2 \mathrm{~mm}$. Before the start of the experiment, the soils were pre-incubated for 10 days at $55 \%$ water holding capacity to reactivate the microbes. This water content was based on Setia et al. (2011) who determined the water content that resulted in maximal soil respiration for soils of different texture and found that for soils with $10-20 \%$ clay $55 \%$ water holding capacity resulted in the highest respiration. Compost from garden waste was separated by dry sieving into the following fractions: $>5 \mathrm{~mm}, 3-5 \mathrm{~mm}$ and $<3 \mathrm{~mm}$. These fractions were air-dried and analysed for various properties (Table 2). The different compost fractions were added to the soils at a rate of $50 \mathrm{mg}$ total $\mathrm{P} \mathrm{kg}^{-1}$ soil and throughly mixed into the soils. The controls (without compost addition) were mixed similarly. The soil $(30 \mathrm{~g})$ was filled into PVC cores (radius $1.85 \mathrm{~cm}$ and height $5 \mathrm{~cm})$ with a nylon mesh base $(0.75 \mu \mathrm{m}$. Australian Filter Specialist) and incubated at $22-25^{\circ} \mathrm{C}$ for 50 days. On days 0,25 and 50, destructive samples were taken to measure microbial biomasss $\mathrm{C}$ and $\mathrm{P}$ pools. The samples at day 0 were taken approximately $5 \mathrm{~h}$ after compost addition. At each sampling date, there were four replicates per compost fraction and soil.

\subsection{Soil and compost fraction analyses}

Soil particle size was determined by the hydrometer method (Ashworth et al., 2001). Electrical conductivity and $\mathrm{pH}$ were measured in a 1:5 soil water ratio after 1 hour end-over-end shaking at $25^{\circ} \mathrm{C}$. Total organic $\mathrm{C}$ was analysed with potassium dichromate and sulphuric acid digestion method as described by Walkley and Black (1934). The water holding capacity of the soils was measured using a sintered glass funnel connected to a $100 \mathrm{~cm}$ water column $(\psi \mathrm{m}=-10 \mathrm{kPa})($ Klute, 1986). 
Table 1.Properties of the soils used in the experiment ( $\mathrm{n}=4, \pm$ standard deviation).

\begin{tabular}{llccc}
\hline Properties & Unit & Mount Bold soil (A) & Birchip soil (B) & Birchip soil (C) \\
\hline Sand & $\%$ & 53 & 84.5 & 84.5 \\
Clay & $\%$ & 20 & 13.0 & 13.0 \\
Silt & $\%$ & 27 & 2.5 & 2.5 \\
pH & & $4.8^{ \pm 0.02}$ & $6.1^{ \pm 0.04}$ & $8.1^{ \pm 0.01}$ \\
Electrical conductivity & $\mathrm{dS} \mathrm{m}$ & $50.2^{-1}$ & $51.8^{ \pm 0.01}$ & $129.1^{ \pm 1.14}$ \\
Total organic C & $\mathrm{g} \mathrm{kg}^{-1}$ & $37.6^{ \pm 0.32}$ & $5.5^{ \pm 0.06}$ & $8.3^{ \pm 0.13}$ \\
Available P & $\mathrm{mg} \mathrm{kg}^{-1}$ & $11.0^{ \pm 0.07}$ & $13.6^{ \pm 0.33}$ & $14.8^{ \pm 0.24}$ \\
Total P & $\mathrm{g} \mathrm{kg}^{-1}$ & $0.4^{ \pm 0.01}$ & $0.1^{ \pm 0.00}$ & $0.2^{ \pm 0.01}$ \\
Total N & $\mathrm{g} \mathrm{kg}^{-1}$ & $2.9^{ \pm 0.07}$ & $0.4^{ \pm 0.01}$ & $0.7^{ \pm 0.02}$ \\
Bulk density & $\mathrm{g} \mathrm{cm}^{-3}$ & 1.4 & 1.6 & 1.6 \\
\hline
\end{tabular}

Table 2. Properties of compost fractions with particles $>5 \mathrm{~mm}, 3-5 \mathrm{~mm}$ or $<3 \mathrm{~mm}$ ( $\mathrm{n}=4, \pm$ standard deviation)

\begin{tabular}{llccc}
\hline Properties & Unit & $>\mathbf{5 ~ m m}$ & $\mathbf{3 - 5} \mathbf{~ m m}$ & $<\mathbf{3 ~ m m}$ \\
\hline $\mathrm{pH}$ & & $8.8^{ \pm 0.01}$ & $8.5^{ \pm 0.01}$ & $8.5^{ \pm 0.01}$ \\
Electrical conductivity & $\mathrm{dS} \mathrm{m}^{-1}$ & $1.8^{ \pm 0.1}$ & $1.9^{ \pm 0.01}$ & $1.9^{ \pm 0.01}$ \\
Available P & $\mathrm{mg} \mathrm{kg}^{-1}$ & $26.9^{ \pm 0.9}$ & $52.7^{ \pm 1.42}$ & $44.9^{ \pm 0.71}$ \\
Available P added & $\mathrm{mg} \mathrm{kg}^{-1}$ & 0.7 & 1.4 & 1.0 \\
Total P & $\mathrm{g} \mathrm{kg}^{-1}$ & $1.8^{ \pm 0.3}$ & $1.8^{ \pm 0.21}$ & $2.3^{ \pm 0.09}$ \\
Total P added & $\mathrm{mg} \mathrm{kg}^{-1}$ & 50 & 50 & 50 \\
Total N & $\mathrm{g} \mathrm{kg}^{-1}$ & $9.3^{ \pm 0.7}$ & $12.8^{ \pm 0.95}$ & $13.1^{ \pm 0.51}$ \\
Total N added & $\mathrm{g} \mathrm{kg}^{-1}$ & 0.3 & 0.4 & 0.3 \\
Total organic C & $\mathrm{g} \mathrm{kg}^{-1}$ & $147^{ \pm 1.5}$ & $149^{ \pm 0.71}$ & $155^{ \pm 0.19}$ \\
Total Organic C added & $\mathrm{g} \mathrm{kg}^{-1}$ & 4.1 & 4.0 & 3.4 \\
C/P ratio & & 82 & 83 & 67 \\
C/N ratio & & 16 & 12 & 12 \\
\hline
\end{tabular}


Soil respiration was measured with a Servomex 1450 series food pack infrared gas analyser from day 0 to 25 for cores to be destructively sampled on day 25 and from day 26 to day 50 for cores to be destructively sampled on day 50 . On day 0 , the cores to be sampled on day 25 were immediately placed in $1 \mathrm{~L}$ glass jars closed with air tight lids equipped with septa to measure respiration. The remaining cores were incubated under the same temperature conditions in large plastic containers. On day 25 the cores placed in jars on day 0 were removed and replaced by those which had been incubating in the plastic containers. The second set of cores was destructively sampled on day 50 . The water content of the soils was maintained by weight, water loss from the soils was minimized by placing containers with water in the jars and large plastic containers. For determination of soil respiration, the $\mathrm{CO}_{2}$ concentration in the head space was measured after sealing the jars ( $(0)$. The closed jars were then incubated in the dark at $22-25^{\circ} \mathrm{C}$ for $1-4$ days (shorter period at the start of the experiment, longer towards the end when respiration rates were low) and then second measurement of the $\mathrm{CO}_{2}$ concentration was taken (t1). After the second measurement,the jars were opened to refresh the air using a fan. The $\mathrm{CO}_{2}$ evolved from each sample was calculated as the difference between $\mathrm{t} 1$ and $\mathrm{t} 0$ for each measurement interval. The relationship between detector response and $\mathrm{CO}_{2}$ concentration was determined by injecting known amounts of $\mathrm{CO}_{2}$ injected into jars similar to those used for soil incubation and calculating the linear regression between detector reading and $\mathrm{CO}_{2}$ concentration. The calculated $\mathrm{CO}_{2}$ concentration was multiplied by the gas volume of the jars to obtain the $\mathrm{mL}$ of $\mathrm{CO}_{2}-\mathrm{C}$ respired during each measurement period and divided by the soil dry weight.

Microbial biomass $\mathrm{C}$ was estimated by fumigationextraction (Vance et al., 1987) on days 25 and 50 after compost addition using $10 \mathrm{~g}$ soil. The soil samples were fumigated for $24 \mathrm{hr}$ with ethanol-free $\mathrm{CHCl}_{3}$ and extracted with $0.5 \mathrm{M} \mathrm{K}_{2} \mathrm{SO}_{4}$. The $\mathrm{C}$ concentration in the filtered extracts was determined by titration with $0.0667 \mathrm{M} \mathrm{K}_{2} \mathrm{Cr}_{2} \mathrm{O}_{7}$ and sulphuric acid (Anderson and Ingram, 1993).The remaining dichromate was titrated with $0.033 \mathrm{M}$ acidified $\left(\mathrm{NH}_{4}\right)_{2} \mathrm{Fe}\left(\mathrm{SO}_{4}\right) 2.6 \mathrm{H}_{2} \mathrm{O}$.
Chloroform-labile $\mathrm{C}$ was calculated as difference between fumigated and non-fumigated soil. To obtain microbial biomass $\mathrm{C}$, the chloroform-labile $\mathrm{C}$ concentration was multiplied by 2.64 (Vance et al., 1987).

Total $\mathrm{N}$ was determined by wet oxidation with sulphuric acid and hydrogen peroxide (Parkinson and Allen, 1975). Total $\mathrm{P}$ was measured after digestion with a mixture of nitric acid and perchloric acid (6:1) (Kuo, 1996) and $\mathrm{P}$ in digest was measured colorimetrically (Murphy and Riley, 1962). Available and microbial $\mathrm{P}$ were analysed using anion exchange resin as described by Kouno et al. (1995). Microbial $\mathrm{P}$ was calculated as the difference between the $\mathrm{P}$ concentration with or without hexanol (Kouno et al., 1995). Soil P pools were analysed using sequential fractionation as described by Hedley et al. (1982) and Tiessen and Moir (1993) with some modifications. One $\mathrm{g}$ of soil was placed in $50 \mathrm{~mL}$ centrifuge tubes and sequentially extracted (at 1:30 soil: solution ratio) with deionised water, $0.5 \mathrm{M} \mathrm{NaHCO}_{3}, 0.1 \mathrm{M}$ $\mathrm{NaOH}, 1 \mathrm{M} \mathrm{HCl}$ and again $0.1 \mathrm{M} \mathrm{NaOH}$. The two $\mathrm{NaOH}$ extracts were combined. The soil was shaken with the extractantson a reciprocating shaker at 200 rev $\mathrm{min}^{-1}$ for $16 \mathrm{~h}$, centrifuged $(1610 \times \mathrm{g})$ and filtered through Whatman filter paper \#42. Ten $\mathrm{mL}$ of filtered extract from the $\mathrm{NaHCO}_{3}$ and $\mathrm{NaOH}$ fractions was acidified to $\mathrm{pH} 1.5$ to precipitate organic matter. The supernatant was centrifuged $(1610 \times \mathrm{g})$, filtered and analysed for inorganic P. Total P in these fractions was determined as described by Huang and Zhang (2009). Five $\mathrm{mL}$ of extract was digested with $1 \mathrm{~mL}$ of $5 \%$ potassium persulphate at $90^{\circ} \mathrm{C}$ for 16 hours which converts organic $\mathrm{P}$ into inorganic $\mathrm{P}$ and analysed for total P. Organic $\mathrm{P}$ of these fractions was calculated as difference between total $\mathrm{P}$ and inorganic $\mathrm{P}$ (measured in the undigested aliquot). Residual $\mathrm{P}$ from residual soil was determined by digestion with $\mathrm{HNO}_{3}-\mathrm{HClO}_{4}$ (6:1). The $\mathrm{P}$ concentration in the fractions was determined colorimetrically at $712 \mathrm{~nm}$ (Murphy and Riley, 1962). 


\subsection{Statistical analyses}

The experiment was arranged in a complete randomized block design with three fixed factors (soil type, compost particle size and sampling time) and four replicates per treatment. The data was analysed by three-way analysis of variance (Gen Stat for windows 11.0, VSN Int. Ltd, UK, 2005). The LSD values for the interaction between type, compost particle size and time refer to $p \leq 5 \%$. Tukey test and linear regression were used to determine significant differences and correlations.

Principal component analysis was carried out using the P pools as variables and soil properties as environmental factors for each sampling date separately (Primer-E Ltd, Plymouth Marine Laboratory, Plymouth, UK).

\section{Results}

The soils differed in range of properties (Table 1). The Mount Bold soil (soil A) had the finest texture and lowest $\mathrm{pH}$, but highest organic matter content and total $\mathrm{N}$ concentration. The two soils from Birchip (soil B and C) had similar sand content which was higher than that in soil $\mathrm{A}$, but differed in $\mathrm{pH}$. Soil $\mathrm{B}$ had a near neutral $\mathrm{pH}$ whereas soil $\mathrm{C}$ was alkaline. Compared to soil $\mathrm{B}$, soil $\mathrm{C}$ had a higher $\mathrm{EC}$ and higher total $\mathrm{P}$, total $\mathrm{N}$ and organic $\mathrm{C}$ concentrations.

The compost size fractions did not differ in $\mathrm{pH}$ and $\mathrm{EC}$, but the available $\mathrm{P}$ concentration was highest in 3-5 $\mathrm{mm}$ fraction whereas the total $\mathrm{P}$ concentration was highest in the $<3 \mathrm{~mm}$ fraction (Table 2). However it should be noted that the total $\mathrm{P}$ concentration added was $50 \mathrm{mg}$ total $\mathrm{P} \mathrm{kg}^{-1}$ soil for all three fractions. Total $\mathrm{C}$ and $\mathrm{N}$ concentrations were highest in the $<3 \mathrm{~mm}$ fraction, but the $\mathrm{C} / \mathrm{N}$ ratio was highest in the $>5 \mathrm{~mm}$ fraction. The amounts of $\mathrm{C}$ and $\mathrm{N}$ added were greatest in the $<3 \mathrm{~mm}$ fraction.

\subsection{Soil respiration and microbial biomass}

In the amended and unamended soils, cumulative respiration was highest in soil A and lowest in soil B (Figure 1). Compost addition increased cumulative respiration in all soils with the increase being greatest with the $>5 \mathrm{~mm}$ fraction and smallest with the $<3 \mathrm{~mm}$ fraction. Compared to the unamended soil, the relative increase in cumulative respiration by compost addition was greatest in soil C. In soils B and C, cumulative respiration was greater from day 26 to day 50 than from day 0 to day 25 .

On day 25, the microbial biomass $\mathrm{C}$ (MBC) concentration was similar in the unamended soils, but on day 50 it was highest in soil B (Figure 2). Compared to the unamended soils, addition of all fractions increased the MBC concentration on day 25 in soil A whereas the MBC concentration was increased in soil B only the $3-5 \mathrm{~mm}$ fraction and in soil $\mathrm{C}$ by the $3-5 \mathrm{~mm}$ and $>5 \mathrm{~mm}$ fractions. On day 50, all compost fractions increased the $\mathrm{MBC}$ concentration compared to the unamended treatment in soil A whereas it was increased in soils $\mathrm{B}$ and $\mathrm{C}$ only some compost fractions: $<3 \mathrm{~mm}$ in soil $\mathrm{B}$ and $>5 \mathrm{~mm}$ and $3-5 \mathrm{~mm}$ in soil $\mathrm{C}$.

\subsection{Phosphorus pools}

In the unamended soils, the available $\mathrm{P}$ concentration was lowest in soil A and highest in soil C (Table 3). Compost addition increased the available $\mathrm{P}$ concentration on days 25 and 50 with a significantly greater increase with the fine fractions $(3-5 \mathrm{~mm}$ and $<3$ $\mathrm{mm}$ ) than the coarser fraction. In the amended soils, the available $\mathrm{P}$ concentration increased over time in soils $\mathrm{B}$ and $\mathrm{C}$ where as it was highest on day 25 in soil A.

The increase in available $\mathrm{P}$ concentration by the compost fractions on days 25 and 50 was greatest in soil A. Only in the unamended soil A, the available $P$ concentration decreased over time. 


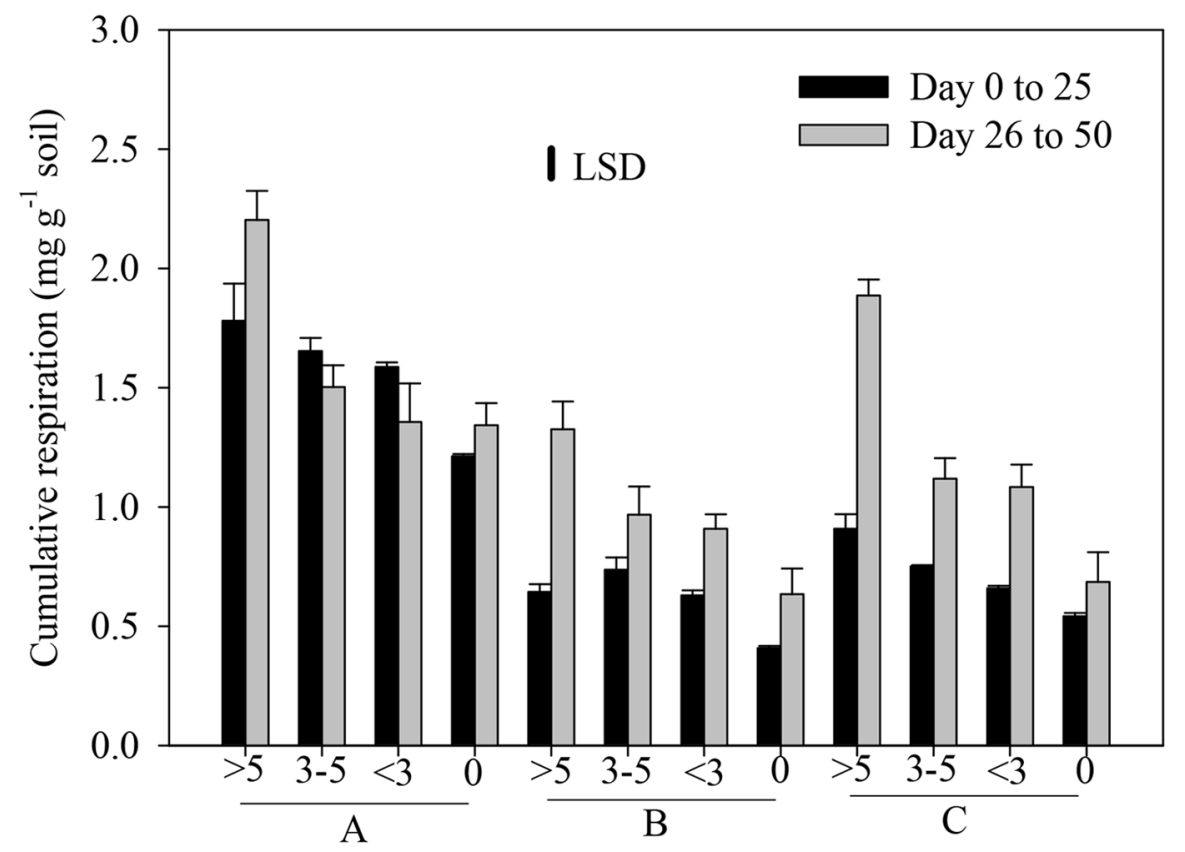

Figure 1. Cumulative respiration ( $\mathrm{mg} \mathrm{g}^{-1}$ soil) in soils $\mathrm{A}, \mathrm{B}$ and $\mathrm{C}$ amended with different compost fractions: $>5 \mathrm{~mm}$, $3-5 \mathrm{~mm}$ and $<3 \mathrm{~mm}$ and unamended soils ( 0 ) from day 0 to day 25 and from day 26 to day 50 ( $\mathrm{n}=4$, the error bar on the columns is the standard deviation). Thick vertical line indicates LSD ( interaction between soil type $\times$ compost fractions $\times$ days).

In the unamended soils, the water-soluble $\mathrm{P}$ concentration was lowest in soil A and highest in soil B (Figure 3). Irrespective of the size fraction, compost addition increased the water-soluble $\mathrm{P}$ concentration in soil A at all sampling dates. In soil $\mathrm{B}$, addition of the $3-5 \mathrm{~mm}$ and $<3 \mathrm{~mm}$ fraction increased the water-soluble $\mathrm{P}$ concentration on day 25 but not on day 50 . In soil C, addition of all fractions increased the water-soluble $\mathrm{P}$ concentration on day 25 whereas on day 50 it was increased only by the $3-5$ and $<3 \mathrm{~mm}$ fractions. Only in soil A, microbial P increased over time. In this soil, addition of compost fractions increased the microbial $\mathrm{P}$ concentration on day 50 . In soil $\mathrm{B}$, the microbial P concentration on day 25 was increased compared to the unamended soil by the addition of the $3-5 \mathrm{~mm}$ and $<3 \mathrm{~mm}$ fractions and on day 50 by addition of $>5 \mathrm{~mm}$ and $<3 \mathrm{~mm}$ fractions. In soil $\mathrm{C}$ compared to the unamended soil, the microbial $\mathrm{P}$ concentration was increased only by addition of the 3-5 $\mathrm{mm}$ fraction on day 25 .

The concentration of $\mathrm{NaHCO}_{3}$-Pi was lower in soil A than in the other two soils A than in the other soils whereas the reverse was true for $\mathrm{NaHCO}_{3}$-Po (Figure $3)$. Addition of the compost fractions increased the concentration of $\mathrm{NaHCO}_{3}$-Pi on days 25 and 50 in all soils with greatest percentage increase in soil A. 
Table 3. Available P concentration ( $\left.\mathrm{mg} \mathrm{kg}^{-1}\right)$ in soils A, B and C amended with different compost particle sizes: $>5 \mathrm{~mm}$, 3-5 mm and $<3$ mmand unamended soils $(0)(n=4, \pm$ standard deviation). The LSD refers to the interaction of soil type, compost fraction and time.

\begin{tabular}{lcccc}
\hline Soils & Compost fractions & Day 0 & Day 25 & Day 50 \\
\hline $\mathrm{A}$ & $>5 \mathrm{~mm}$ & $11.9^{ \pm 0.2}$ & $16.7^{ \pm 0.2}$ & $10.6^{ \pm 0.5}$ \\
& $3-5 \mathrm{~mm}$ & $12.9^{ \pm 0.1}$ & $22.6^{ \pm 0.4}$ & $17.4^{ \pm 0.7}$ \\
& $<3 \mathrm{~mm}$ & $12.6^{ \pm 0.3}$ & $23.2^{ \pm 0.2}$ & $16.1^{ \pm 0.1}$ \\
& 0 & $11.0^{ \pm 0.1}$ & $9.7^{ \pm 0.4}$ & $6.2^{ \pm 0.1}$ \\
\hline $\mathrm{B}$ & $>5 \mathrm{~mm}$ & $14.2^{ \pm 0.2}$ & $15.7^{ \pm 0.2}$ & $17.1^{ \pm 0.4}$ \\
& $3-5 \mathrm{~mm}$ & $14.6^{ \pm 0.2}$ & $19.1^{ \pm 0.6}$ & $22.6^{ \pm 0.5}$ \\
& $<3 \mathrm{~mm}$ & $14.2^{ \pm 0.2}$ & $18.8^{ \pm 0.6}$ & $18.3^{ \pm 0.4}$ \\
& 0 & $13.7^{ \pm 0.3}$ & $13.4^{ \pm 0.3}$ & $13.4^{ \pm 0.2}$ \\
\hline $\mathrm{C}$ & $>5 \mathrm{~mm}$ & $15.5^{ \pm 0.3}$ & $17.3^{ \pm 0.4}$ & $17.4^{ \pm 0.1}$ \\
& $3-5 \mathrm{~mm}$ & $16.1^{ \pm 0.4}$ & $17.8^{ \pm 0.9}$ & $22.2^{ \pm 0.6}$ \\
& $<3 \mathrm{~mm}$ & $15.7^{ \pm 0.2}$ & $18.5^{ \pm 0.6}$ & $20.2^{ \pm 0.5}$ \\
& 0 & $14.8^{ \pm 0.2}$ & $17.2^{ \pm 0.1}$ & $16.0^{ \pm 0.1}$ \\
\hline LSD & & & 1.06 & \\
\hline
\end{tabular}

In soil $\mathrm{A}$, the increase was not affected by compost particle size whereas in soils $\mathrm{B}$ and $\mathrm{C}$, the increase was smallest with the coarsest fraction $(>5 \mathrm{~mm}$ ). The concentration of $\mathrm{NaHCO}_{3}$-Pi changed over time in the amended soils but differently in the three soils; with time it increased in soil A, decreased in soil $\mathrm{B}$; and peaked on day 25 in soil C. Compared to the unamended soil, addition of compost fractions increased the concentration of $\mathrm{NaHCO}_{3}-\mathrm{Po}$ on day 0 in soils $\mathrm{B}$ and $\mathrm{C}$. On day 25 , the $\mathrm{NaHCO}_{3}-\mathrm{Po}$ concentration was increased in soil $\mathrm{B}$ by addition of the $3-5 \mathrm{~mm}$ and $<3 \mathrm{~mm}$ fractions and in soil $\mathrm{C}$ by the $>5 \mathrm{~mm}$ fraction. On day 50 , only in soil A the addition of $>5 \mathrm{~mm}$ and 3-5 $\mathrm{mm}$ fractions increased the concentration of $\mathrm{NaHCO}_{3}-\mathrm{Po}$. The $\mathrm{NaHCO}_{3}-\mathrm{Po}$ decreased over time in the amended soils $\mathrm{B}$ and $\mathrm{C}$.

The concentrations of $\mathrm{NaOH}-\mathrm{Pi}$ and $\mathrm{Po}$ were greatest in soil A (Figure 4). Compost addition had little effect on the NaOH-Po concentration but increased the $\mathrm{NaOH}-\mathrm{Pi}$ concentration in soil A.

Both NaOH-Pi and Po concentrations were maximal on day 25 in the amended soil A, whereas there was little temporal change in soils B and C. On day 25 in soil $\mathrm{A}$, addition of the $3-5 \mathrm{~mm}$ and $<3 \mathrm{~mm}$ fractions significantly increased $\mathrm{NaOH}-\mathrm{Pi}$ concentration compared to the $>5 \mathrm{~mm}$ fraction. 
The compost fractions did not differ in their effect on the $\mathrm{NaOH}-\mathrm{Po}$ concentration.

The concentration of HCl-P was highest in soil $\mathrm{C}$ and lowest in soil A (Figure 4). Addition of the compost fractions increased the concentration of HCl-P on days 25 and 50 in all soils with the greatest increase by the $3-5 \mathrm{~mm}$ fraction on day 50 in soils B and C. In all amended soils, the $\mathrm{HCl}-\mathrm{P}$ concentration was significantly higher on days 25 and 50 than on day 0.

The residual $\mathrm{P}$ concentration was higher in soil A than in soils B and C (Figure 4). Compost addition did not change the concentration of residual $\mathrm{P}$ and it did not change over time. The PCA plots based on the P pools show a clear separation of soil A from soils B and C at all sampling dates (Figure 5). This separation is based on the higher concentration of organic $\mathrm{NaHCO}_{3}$ and $\mathrm{NaOH}, \mathrm{NaOH}-\mathrm{Pi}$, total and residual $\mathrm{P}$ in soil $\mathrm{A}$ whereas the concentration of $\mathrm{NaHCO}_{3}-\mathrm{Pi}$, available $\mathrm{P}$ and $\mathrm{HCl}-\mathrm{P}$ were higher in soils $\mathrm{B}$ and $\mathrm{C}$. The separation of soils B and C along PC2 is based on higher concentrations of water-soluble $\mathrm{P}$ in soil $\mathrm{B}$. The concentration of microbial $\mathrm{P}$ was higher in soil $\mathrm{C}$ on day 0 and 25, but on day 50 it was highest in soil A. The comparison of the loadings of the P pools with those of the soil properties (Table 4) shows that water-soluble $\mathrm{P}$ was positively correlated with sand content whereas the concentration of $\mathrm{NaHCO}_{3}-\mathrm{Po}, \mathrm{NaOH}-\mathrm{Po}$, residual and total $\mathrm{P}$ were correlated with silt and clay content as well as TOC and TN concentrations. The $\mathrm{pH}$ was correlated with the concentration of HCl-P (Table 4).

\section{Discussion}

The differences between the soils in the measured properties were greater than among the compost fractions. Compost addition increased microbial activity and biomass as well as the concentration of most $\mathrm{P}$ pools except $\mathrm{NaOH}-$ Po and residual $\mathrm{P}$ with only small differences among the compost size fractions. This study also showed that the $\mathrm{P}$ pools concentration is predominantly affected by soil properties such as organic matter, texture and $\mathrm{pH}$.
Soil A differed in the concentration of the organic pools and total P from the other two soils and the PCA showed that this can be explained by its higher organic matter content, lower $\mathrm{pH}$ and fine texture. The high organic matter content also resulted in higher microbial biomass, cumulative respiration in soil A compared to the other two soils.

The higher $\mathrm{pH}$ in soil $\mathrm{C}$ can explain the higher concentration of $\mathrm{HCl}-\mathrm{P}$ which represents $\mathrm{P}$ associated with calcium (Lee et al., 2004). The effect of soil texture on soil $\mathrm{P}$ pools was evident in the higher concentrations of water-soluble $\mathrm{P}$ in the two coarser textured soils compared to soil A. Sand would have fewer potential $\mathrm{P}$ binding sites than clay and silt, thus $\mathrm{P}$ would remain in water-soluble form in soils with a higher percentage sand. The fine texture of soil A is likely to have indirectly affected the size of the $\mathrm{P}$ pools by the higher organic matter content. The higher organic matter content can be explained by the increased plant input due to the higher soil fertility as well as protection of organic matter in aggregates (Baldock 2007). The higher proportion of $\mathrm{NaOH}-\mathrm{P}$ in this soil which represents $\mathrm{P}$ associated with $\mathrm{Al}$ and Fe (Sikora and Corey, 1976) can be explained by the presence of clay which is usually coated with $\mathrm{Fe}$ and $\mathrm{Al}$ hydroxides (Baldock 2007).

\subsection{Differences among compost fractions}

The differences in the measured parameters among the compost fractions were small compared to the differences among the soils. Cumulative respiration was increased in compost amended soils compared to the control soils because of the organic matter addition with compost (Ros et al., 2006). The coarse compost fraction (> $5 \mathrm{~mm}$ ) increased microbial activity more than the other fractions, but not microbial biomass. The higher activity occurred although less total $\mathrm{C}$ was added with this fraction, but because the $\mathrm{C} / \mathrm{N}$ ratio of this fraction was higher, the additional $\mathrm{C}$ could not be used for build-up of microbial biomass and was instead respired. The large increase in microbial biomass in the first 25 days with finest fractions in soils $\mathrm{A}$ and $\mathrm{C}$ can be explained by the larger surface area to volume ratio 
of the fine particles which increases accessibility to soil microbes (Magid et al., 2010). However this great accessibility did not result in higher cumulative respiration suggesting that the $\mathrm{C}$ was preferentially used to for growth rather than respiration. The larger surface area to volume ratio and higher decomposability of the fine fraction can also explain why the finest fraction induced the greatest increase in $\mathrm{NaHCO}_{3}-\mathrm{Pi}$ and resin $\mathrm{P}$ concentrations in soils $\mathrm{A}$ and $\mathrm{B}$. This suggests that compost $\mathrm{P}$ was mineralised to a greater extent during incubation from this fraction than from the coarser fraction. The difference between the compost fractions in $\mathrm{NaHCO}_{3}-\mathrm{Pi}$ and resin $\mathrm{P}$ was not observed in soil $\mathrm{C}$ which had higher concentrations of these pools when unamended. An increase in available $\mathrm{P}$ concentration with organic amendments was also reported by Schefe et al. (2008). In addition to P release during mineralisation this can also be explained by chelation of $\mathrm{Al}$ and $\mathrm{Fe}$ with organic acids formed during decomposition of organic compounds (Hu et al., 2005) which block $\mathrm{P}$ adsorption sites and may mobilise $\mathrm{P}$ from poorly soluble forms (Sanchez and Beck, 1994).

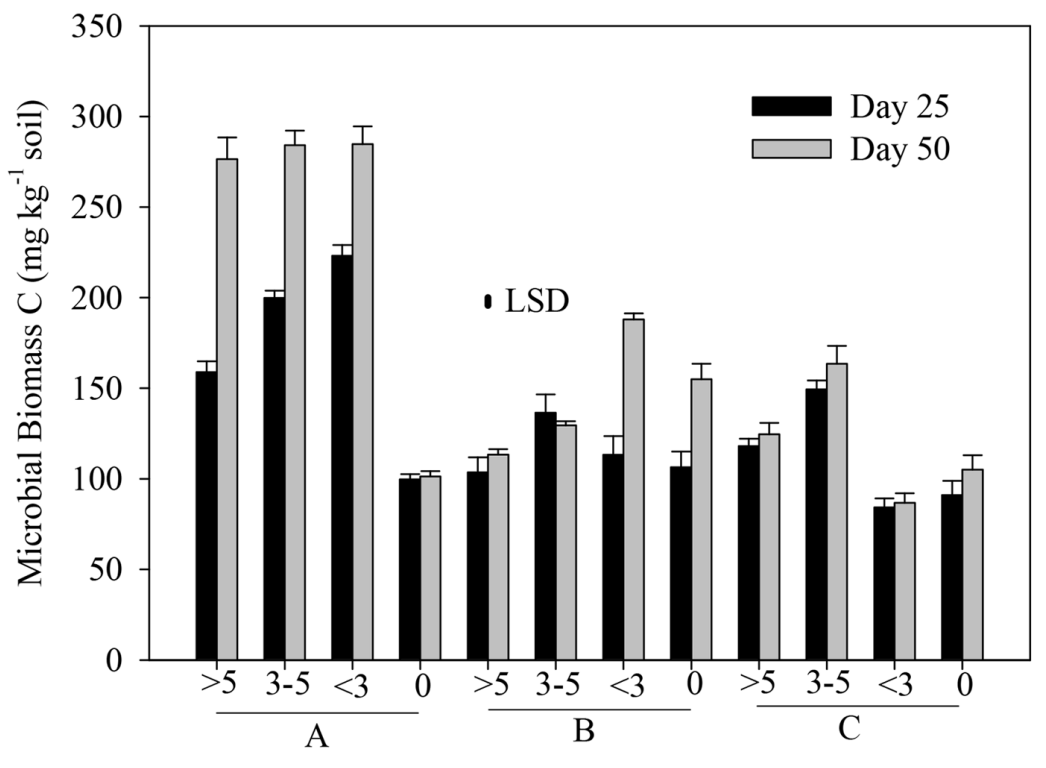

Figure 2. Microbial biomass $\mathrm{C}\left(\mathrm{mg} \mathrm{kg}^{-1}\right.$ soil) in soils $\mathrm{A}, \mathrm{B}$ and $\mathrm{C}$ amended with different compost fractions: $>5 \mathrm{~mm}$, 3-5 $\mathrm{mm}$ and $<3 \mathrm{~mm}$ and unamended soils $(0)$ on day 25 and day $50(\mathrm{n}=4$, the error bar on the columns is the standard deviation). Thick vertical line indicates LSD (interaction soil type $\times$ compost fractions $\times$ days). 


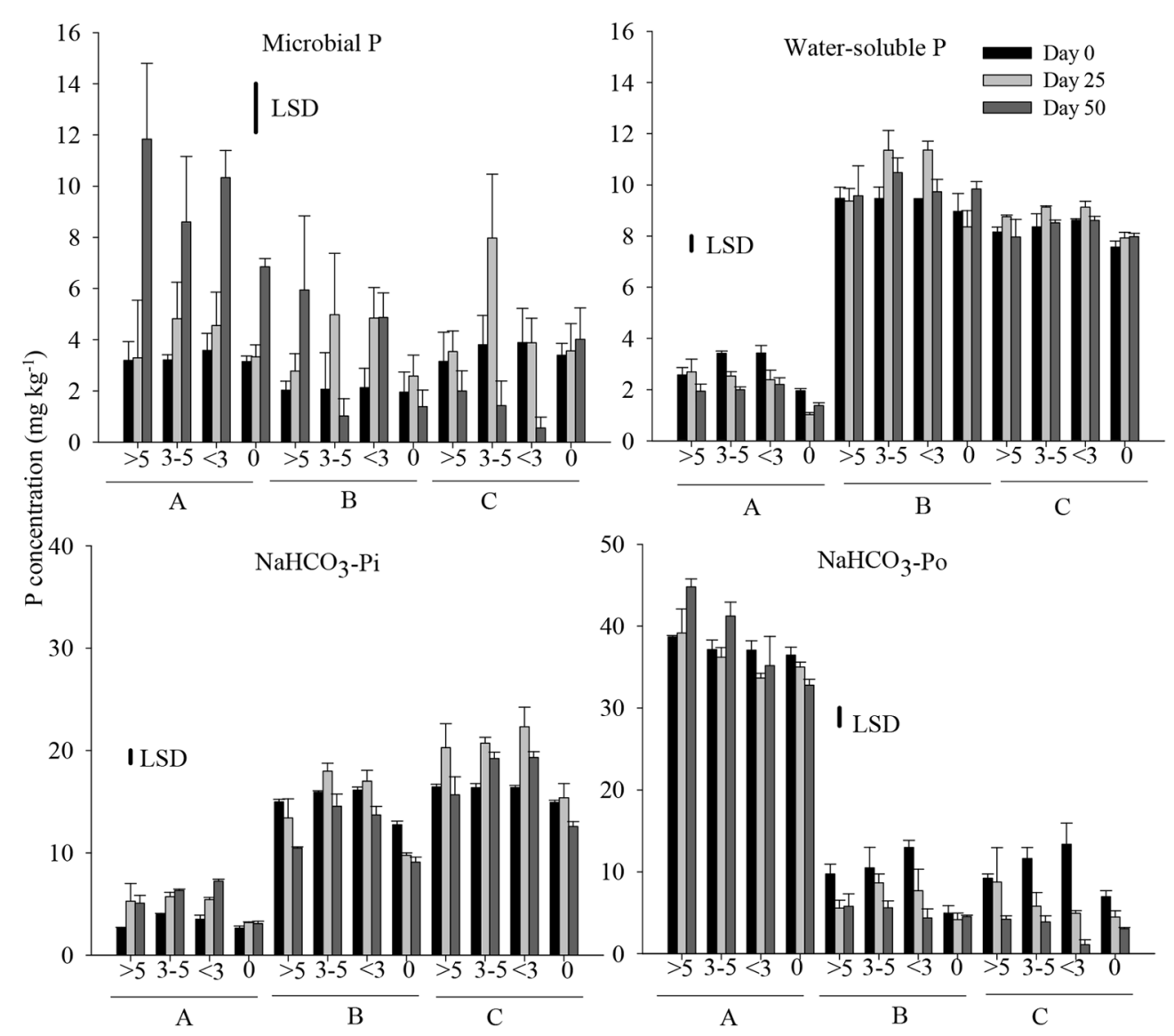

Figure 3. The concentrations of microbial $\mathrm{P}$, water-soulble $\mathrm{P}$ and $\mathrm{NaHCO}_{3}-\mathrm{Pi}$ and $\mathrm{Po}\left(\mathrm{mg} \mathrm{kg}^{-1}\right)$ in soils $\mathrm{A}, \mathrm{B}$ and $\mathrm{C}$ amended with different compost fractions: $>5 \mathrm{~mm}, 3-5 \mathrm{~mm}$ and $<3 \mathrm{~mm}$ and unamended soils $(0)$ on days 0,25 and 50 $(\mathrm{n}=4$, the error bar on the columns is the standard deviation).Thick vertical line indicates LSD (interaction soil type $\times$ compost fractions $\times$ days).

\subsection{Changes in P pools over time}

The concentration of some $\mathrm{P}$ pools that are considered as stable (NaOH-P, HCl-P) changed considerably over the course of the experiment suggesting that they are quite labile. Vu et al. (2010) also found that these stable $\mathrm{P}$ pools are converted into plant available $\mathrm{P}$ and Mat Hassan et al. (2012) found large changes in concentration of these pools in the rhizosphere of legumes and wheat. In the present study, only the residual $\mathrm{P}$ concentration did not change over time. The changes over time in the size of most P pools can be explained by $\mathrm{P}$ release from the added compost (in the amended soils) but also by P flux among the pools, e.g., $\mathrm{NaOH}-\mathrm{Pi}$ being converted to $\mathrm{HCl}-\mathrm{P}$ and $\mathrm{NaOH}-\mathrm{Pi}$ and $\mathrm{NaHCO}_{3}$-Pi taken up by the microbial biomass (Ochwoh et al., 2005). 


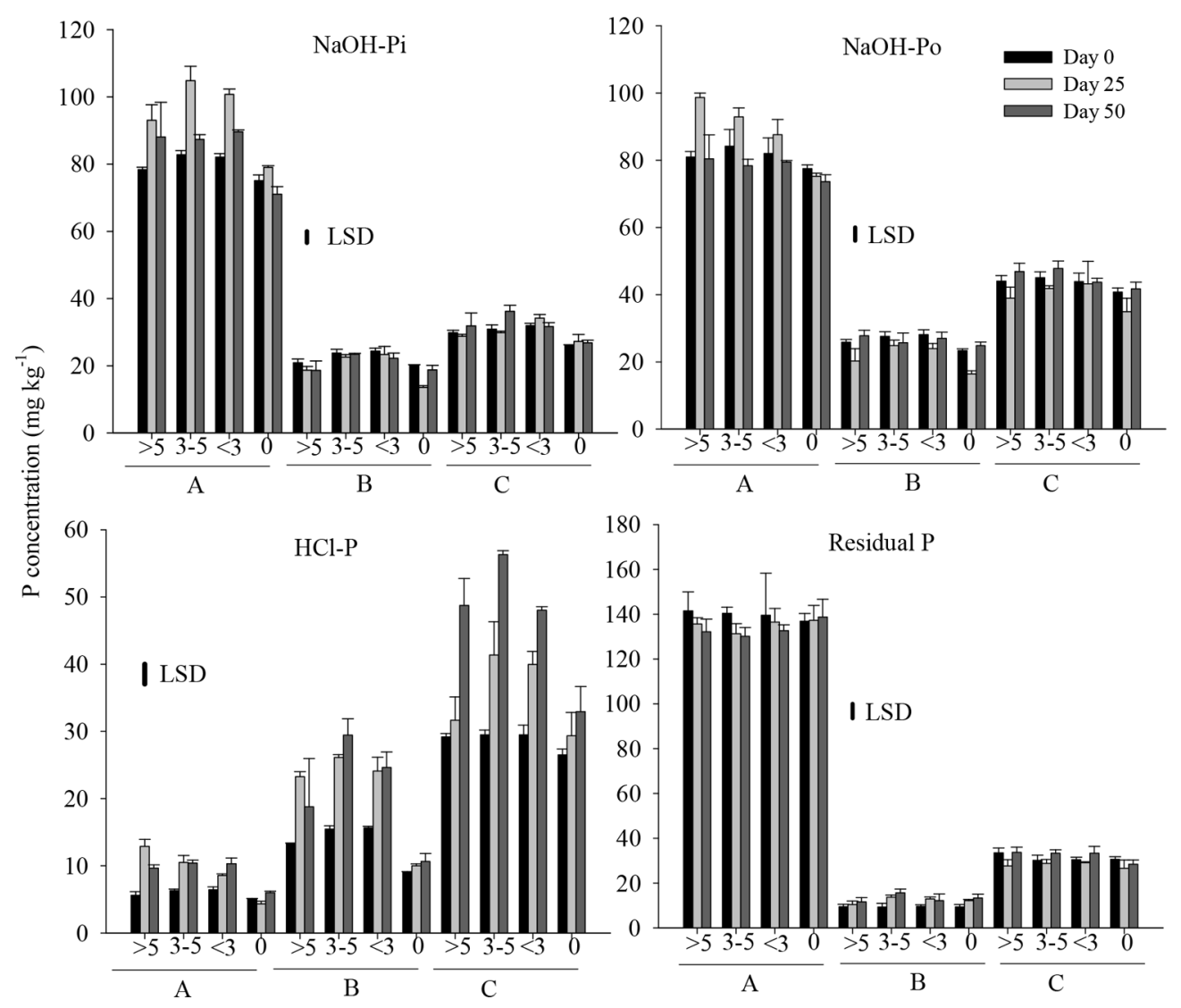

Figure 4. The concentrations of $\mathrm{NaOH}-\mathrm{Pi}$ and $\mathrm{Po}, \mathrm{HCl}-\mathrm{P}$ and residual $\mathrm{P}\left(\mathrm{mg} \mathrm{kg}^{-1}\right)$ in soils $\mathrm{A}, \mathrm{B}$ and $\mathrm{C}$ amended with different compost particle sizes: $>5 \mathrm{~mm}, 3-5 \mathrm{~mm}$ and $<3 \mathrm{~mm}$ and unamended soils $(0)$ on days 0,25 and $50(\mathrm{n}=4)$. Thick vertical line indicates LSD (interaction between soil type $\times$ compost fractions $\times$ days). 

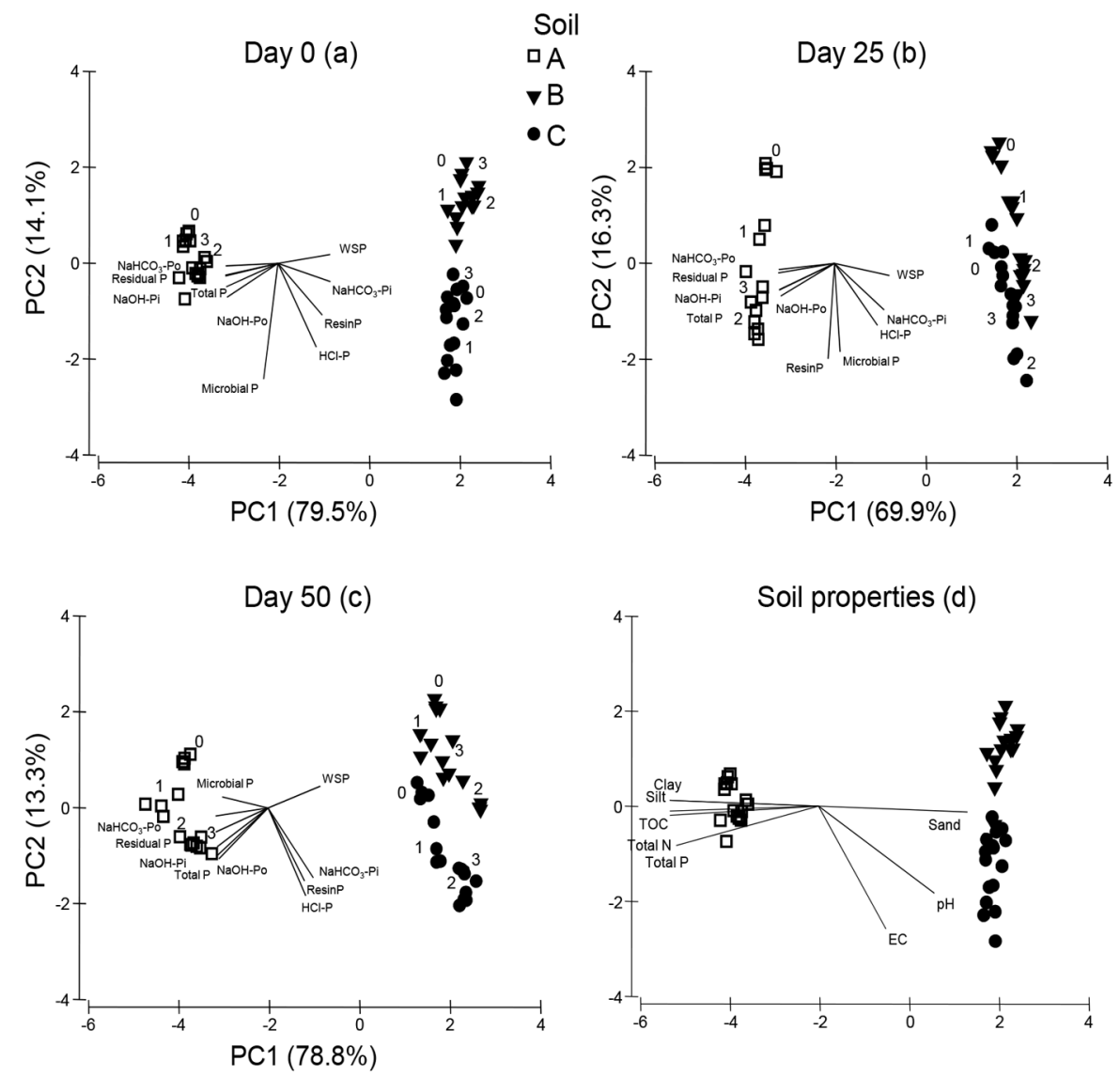

Figure 5. Principal component plots based on P pools on days 0,25 and 50 showing the $P$ pools as vectors $(a, b$ and $c)$ and the corresponding soil properties (d).The plot with the soil properties was the same for all three sampling dates. Symbols $\mathrm{A}, \mathrm{B}$ and $\mathrm{C}$ refer to the three soils, the numbers next to the symbols indicate the compost treatment: 0 unamended control, 1: $>5 \mathrm{~mm}$ fraction, 2: 3-5 $\mathrm{mm}$ fraction, $3:<3 \mathrm{~mm}$ fraction. 
Table 4. Loading of $\mathrm{P}$ pools and environmental factors for PC1 and PC2. For a given pool/factor only the loading of the axis with the higher loading value is shown. The loadings for the P pools are presented separately for each sampling date, the loadings for the environmental factors apply to all 3 sampling dates.

\begin{tabular}{|c|c|c|c|c|c|c|c|c|}
\hline \multirow[b]{2}{*}{ Variable } & \multicolumn{2}{|c|}{ Day 0} & \multicolumn{2}{|c|}{ Day 25} & \multicolumn{2}{|c|}{ Day 50} & \multicolumn{2}{|c|}{ Environmental } \\
\hline & PC1 & PC2 & PC1 & PC2 & PC1 & PC2 & PC1 & PC2 \\
\hline Water-soluble P & 0.35 & & 0.37 & & 0.35 & & & \\
\hline ResinP & 0.30 & & & -0.60 & & -0.49 & & \\
\hline Microbial P & & -0.72 & & -0.55 & -0.31 & & & \\
\hline NaHCO3-Pi & 0.35 & & 0.33 & & -0.35 & -0.44 & & \\
\hline NaHCP3-Po & -0.35 & & -0.37 & & -0.35 & & & \\
\hline $\mathrm{NaOH}-\mathrm{Pi}$ & -0.35 & & -0.37 & & -0.34 & & & \\
\hline $\mathrm{NaOH}-\mathrm{Po}$ & -0.34 & & -0.36 & & -0.33 & & & \\
\hline $\mathrm{HCl}-\mathrm{P}$ & & -0.53 & & -0.39 & & -0.55 & & \\
\hline Residual P & -0.35 & & -0.37 & & -0.35 & & & \\
\hline Total P & -0.34 & & -0.37 & & -0.33 & & & \\
\hline Sand & & & & & & & 0.99 & \\
\hline Silt & & & & & & & -0.99 & \\
\hline Clay & & & & & & & -0.99 & \\
\hline TOC & & & & & & & -0.99 & \\
\hline Total P & & & & & & & -0.94 & \\
\hline Total N & & & & & & & -0.98 & \\
\hline $\mathrm{pH}$ & & & & & & & 0.79 & \\
\hline $\mathrm{EC}$ & & & & & & & & -0.60 \\
\hline
\end{tabular}




\section{Conclusion}

The study showed that the finest compost size fraction increased microbial biomass and $\mathrm{P}$ availability more than the coarser fraction which can be explained by its high surface area volume ratio and higher decomposability compared to the coarser fraction. However, the differences among compost size fractions with respect to their effect on soil $\mathrm{P}$ pools were small; the size of the P pools was mainly a function of soil properties such as organic matter content, texture and $\mathrm{pH}$. It should be noted that we could only measure the net effect of compost addition on soil $\mathrm{P}$ pools. It would be of interest to follow $\mathrm{P}$ from organic amendments (e.g. plant residues) into soil $\mathrm{P}$ pools by using $32 \mathrm{p}$ labelled plant residues

\section{References}

Annabi, M., Houot, S., Francou, C., Poitrenaud, M., Bissonnais, Y.L. 2007. Soil aggregate stability improvement with urban composts of different maturities. Soil Sci.Soc. Amer. J. 71, 413-423.

Anderson, J.M., Ingram, J.S.I. 1993. Tropical Soil Biology and Fertility: A Handbook of Methods, CAB International, Wallingford, England.

Ashworth, J., Keyes, D., Kirk, R., Lessard, R. 2001. Standard procedure in the hydrometer method for particle size analysis. Commun. Soil Sci. Plan. 32, 633-642.

Ayaga, G., Todd, A., Brookes, P.C. 2006. Enhanced biological cycling of phosphorus increases its availability to crops in low-input sub-saharan farming systems. Soil Biol. Biochem. 38,81-90.

Baldock, J.A. 2007. Composition and cycling of organic carbon in soil. In: Nutrient cyling in terrestrial ecosystem (eds Marschner, P., Rengel, Z), Springer Berlin,pp: 1-36.
Bertrand, I., Holloway, R.E., Armstrong, R.D., McLaughlin, M.J. 2003. Chemical characterstics of phosphorus in alkaline soils from Southern Australia, Aust. J. Soil. Res. 41, 61-76.

Doublet, J., Francou, C., Pétraud, J. P., Dignac, M. F., Poitrenaud, M., Houot, S. 2010. Distribution of C and $\mathrm{N}$ mineralization of s sludge compost within particlesize fractions. Biores. Technol. 101, 1254-1262.

Duong, T.T.T., Penfold, C., Marschner, P. 2012 Differential effects of composts on properties of soils with different textures. Biol. Fert. Soil. 48, 699-707.

Fangueiro, D., Bol, R., Chadwick, D., Portugal, V. R. 2008. Assessment of potential $\mathrm{N}$ mineralization of six particle size fractions of two different cattle slurries. J. Plant Nutr. Soil Sci. 171, 313-315.

Ferreras, L., Gomez, E., Toresani, S., Firpo, I., Rotondo, R. 2006. Effect of organic amendments on some physical, chemical and biological properties in a horticultural soil. Biores. Technol. 97, 635-640.

Gómez-Muñoz, B., Bol, R., Hatch, D., Gracía-Ruiz, R. 2011. Carbon mineralization and distribution of nutrients within different particle-size fractions of commercially produced olive mill pomace. Biores. Technol. 102, 9997-10005.

Hedley, M.J., Stewart, J.W.B., Chauhan, B.S. 1982. Changes in inorganic and organic soil-phosphorus fractions induced by cultivation practices and laboratory incubations. Soil Sci. Soc. Am. J. 46, 970-976.

Hu, H., Tang, C., Rengel, Z. 2005. Role of phenolics and organic acids in phosphorus mobilization in calcareous and acidic soils. J. Plant Nutr. 28, 1427-1439.

Huang, X.L., Zhang, J.Z. 2009. Neutral persulfate digestion at -sub-boiling temperature in an oven for total dissolved phosphorus determination in natural waters, Talanta. 78, 1129-1135. 
Hue, N. 1991. Effects of organic acids/anions on $\mathrm{P}$ sorption and phytoavailability in soils with different mineralogies. Soil Sci. 152, 463-471.

Khan, K.S., Joergensen, R.G. 2009. Changes in microbial biomass and $\mathrm{P}$ fractions in biogenic household waste compost amended with inorganic P fertilizers. Biores. Technol. 100, 303-309.

Klute, A. 1986. Water-retention. In: A. Klute (Editor), Methods of soil analysis. Part 1. Physical and mineralogical methods. American Society of Agronomy-Soil Science, Madison, WI, pp:635662.

Kouno, K., Tuchiya, Y., Ando, T. 1995. Measurement of soil microbial biomass phosphorus by an anionexchange membrane method. Soil Biol. Biochem. 27, 1353-1357.

Kuo, S. 1996. Phosphorus. In: D.L. Sparks (Editor), Methods of soil analysis: Chemical methods. Soil Science Society of America Journal, Madison, WI, pp: 869-919.

Lee, C.H., Park, C.Y., Park, K.D., Jeon, W.T., Kim, P. J. 2004. Long-term effects of fertilization on the forms and availability of soil phosphorus in rice paddy. Chemosphere, 56. 299-304.

Magid, J., De Nowina, K., Lindedam, J., Andren, O. 2010. Organic matter in size-density fractions after 16-50 years of grass ley, cereal cropping and organic amendments. Euro. J. Soil. Sci. 61, 539550 .

Mat Hassan, H., Marschner, P., McNeill, A., Tang, C. 2012. Grain legumes pre-crops and their residues affect the growth, $\mathrm{P}$ uptake and size of $\mathrm{P}$ pools in the rhizosphere of the following wheat. Biol. Fert. Soil. 48, 775-785.

Murphy, J., Riley, J. 1962. A modified single solution method for the determination of phosphate in natural waters. Anal. Chim. Acta 27, 31-36.
Ochwoh, V.A., Claassens, A.S., De Jager, P. 2005. Chemical changes of applied and native phosphorus during incubation and distribution into different soil phosphorus pools. Commun. Soil Sci. Plan. 36, 535-556.

Parkinson, J., Allen, S. 1975. A wet oxidation procedure suitable for the determination of nitrogen and mineral nutrients in biological material. Commun. Soil Sci. Plan. 6, 1-11.

Pascual, J.A., García, C., Hernandez, T., Ayuso, M. 1997. Changes in the microbial activity of an arid soil amended with urban organic wastes. Biol. Fertil. Soils 24, 429-434.

Peters, K., Jensen, L.S., Hjorth, M., Magid, J. 2011. Carbon, Nitrogen and Phosphorus distribution in particle-size fractionated pig and cattle slurry. J. Environ. Qual. 40, 224-232.

Ros, M., Pascual, J., Gracía, C., Hernadez, M.T., Insam, H. 2006. Hydrolase activities, microbial biomass and bacterial community in a soil after long-term amendment with different composts. Soil Biol. Biochem. 38, 3443-3452.

Sanchez, P.A., Beck, M.A. 1994. Soil phosphorus fraction dynamics during 18 years of cultivation on a typic paleudult. Soil Sci. Soc. Am. J. 58, 1424-1431.

Schefe, C.R., Patti, A.F., Clune, T.S., Jackson, R. 2008. Organic amendments increase soil solution phosphate concentrations in an acid soil: a controlled environment study. Soil Sci. 173, 267-276.

Setia, R., Marschner, P., Baldock, J., Chittleborough, D., Verma, V. 2011. Relationships between carbon dioxide emission and soil properties in salt-affected landscapes. Soil Biol. Biochem. 43, 667-674

Sikora, L., Corey, R. 1976. Fate of nitrogen and phosphorus in soils under septic tank waste disposal fields. T. Am. Soc. Agri. Eng. 19, 866-870. 
Song, C., Han, S., Tang, C. 2007. Changes in phosphorus fractions, sorption and release in Udic Mollisols under different ecosystems. Biol. Fert. Soil. 44, 37-47.

Tester, C., Taylor, J., Parr, J., Sikora, L. 1979. Decomposition of sewage sludge compost in soil: III. Carbon, nitrogen, and phosphorus transformations in different sized fractions. J. Environ. Qual. 8, 79-82.

Tiessen, H., Moir, J. 1993. Characterization of available $\mathrm{P}$ by sequential extraction. Soil sampling and methods of analysis, Lewis, Boca Raton, FL, pp: $75-86$.

Tognetti, C., Mazzarino, M. J., Laos, F. 2008. Compost of municipal organic waste: Effects of different management practices on degradability and nutrient release capacity. Soil Biol. Biochem. 40, 22902296.
Vance, E., Brookes, P., Jenkinson, D. 1987. An extraction method for measuring soil microbial biomass C. Soil Biol. Biochem. 19, 703-707.

Vu, D., Tang, C., Armstrong, R. 2010. Transformations and availability of phosphorus in three contrasting soil types from native and farming systems: A study using fractionation and isotopic labelling techniques. J. Soil. Sedim. 10, 18-29.

Walkley, A., Black, I.A. 1934. An examination of the Degtjareff method for determining soil organic matter, and a proposed modification of the chromic acid titration method. Soil Sci. 37, 29-38. 